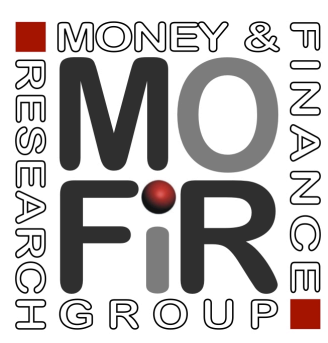

\title{
Aid Effectiveness in FragiLe States
}

\author{
Francesca G. Caselli Andrea F. Presbitero
}

Working paper no. 158

January 2020 


\title{
Aid Effectiveness in Fragile States ${ }^{1}$
}

\author{
Francesca G. Caselli \\ Andrea F. Presbitero
}

September 26, 2019

\begin{abstract}
Fragile states are highly dependent on foreign aid and are characterized by several features that impair their economic and social performance. After reviewing the literature on aid effectiveness, the chapter presents several stylized facts on aid flows to fragile states, and exploits detailed project-level data to provide novel evidence on aid effectiveness in fragile states. Comparing project success rate across fragile and other developing countries confirms that aid given to fragile states is less likely to be effective than elsewhere. Focusing on the conflict dimension of fragility, we can extend our analysis at the subnational level to strengthen the identification of the effect of fragility on project success. Our results indicate that a project implemented in a fragile state is up to 8 percentage points less likely to be successful than a similar project financed in another developing country. Our analysis does not imply that aid to fragile states should be reduced across the board, but points to several factors that could hamper the growth dividend of aid.
\end{abstract}

\footnotetext{
${ }^{1}$ Francesca G. Caselli (corresponding author), International Monetary Fund, email: fcaselli@imf.org; Andrea F. Presbitero, International Monetary Fund, email: apresbitero@imf.org. Paper prepared for the forthcoming book "Macroeconomic Policy in Fragile States" (edited by Ralph Chami, Raphael Espinoza and Peter Montiel, and published by Oxford University Press). We would like to thank Axel Dreher, Valentin Lang, Peter Montiel for helpful comments and feedbacks. We also thank Kai Gehring, Lennart Kaplan and Melvin Wong for sharing subnational data on conflicts and on World Bank projects. The views expressed in this paper are those of the authors and do not necessarily represent the views of the IMF, its Executive Board, or IMF management.
} 


\section{Introduction}

In 2017 foreign aid to developing countries - measured by official development assistance (ODA) grants - amounted to more than USD 140 billion. $^{2}$ A large (and increasing) share of these flows have been directed to fragile states, which received USD 68 billion in 2016 (OECD 2018). In fragile states, aid inflows account for a much larger share of GDP than in other developing countries and, on average, it is the most important source of external finance. Fragile states are highly dependent on foreign aid and are also characterized by several features that impair their economic and social performance-encompassing weak governance, limited administrative capacity, low legitimacy, chronic humanitarian crises, polarized societies and persistent social tensions, and, often, violence or the legacy of armed conflict and civil war (OECD 2018; Commission on State Fragility, Growth and Development 2018). Thus, two questions arise: how predictable and, more important, effective are aid inflows to fragile states?

The experience of Malawi is a case in point. Foreign aid amounted to 17 percent of GDP between 2005 and 2008 and in the same period the country grew at 6.3 percent per year (in real terms), a rate significantly higher than in previous years. ${ }^{3}$ Commentators praised Malawi for "its sound economic policies and a supportive donor environment" (Wroe 2012). However, in 2009 the situation changed dramatically as aid money was used for personal expenditures and human rights and international observers raised governance concerns (IMF 2012). These events triggered a reaction by the international community and a steady decline in foreign assistance (aid averaged 12.5 percent of GDP in 2009-11, the decline in Malawi was bigger than the decline in aid due to the financial crisis in some donor countries), which created mounting pressure on the exchange rate and led to significant negative real effects and a growth slowdown in subsequent years. The case of Malawi would suggest that aid can be a key driver

\footnotetext{
2 Data are from the OECD, http://www.oecd.org/newsroom/development-aid-drops-in-2018-especially-toneediest-countries.htm (last accessed: June 2019)

${ }^{3}$ Data are from the World Bank’s World Development Indicators (last accessed: June 2019).
} 
of sustained growth, even in fragile states. However, weak governance can undermine aid effectiveness and lead to volatile inflows, which are likely to adversely affect fragile states.

Given that fragile countries are at the risk of being left behind - it has been estimated that by 2030 more than 80 percent of the world's poorest will live in fragile countries (OECD 2018) there is ground to advocate for additional and increasing aid inflows to fragile states. For instance, in 2015 the UK's Department for International Development (DFID) made the commitment to allocate 50 percent of its budget to fragile states and regions (DFID 2015). Similarly, the United States - which is the largest donor to fragile states - is scaling up its effort to tackle fragility (D'Alelio 2018). Multilateral institutions are also taking steps in the same direction. The World Bank agreed to double its funding for fragile, conflict, and violence-affected countries ${ }^{4}$, while the IMF (2017) has published a comprehensive review of its technical assistance programming in fragile states with a set of recommendations for improving fiscal capacity.

However, the literature on the effects of foreign aid on growth and poverty reduction has not yet reached a consensus on aid effectiveness, and fragile states are characterized by elements (e.g., weak institutions, conflicts) which could weaken aid effectiveness. Moving from similar concerns, and to maximize aid effectiveness and lift countries out of fragility, the Commission on State Fragility, Growth and Development (2018) recommends to develop aid strategies specific to fragile states in order to channel aid flows to strategic sectors, finance key public investment projects necessary to emerge from political and economic fragility, and promote job creation.

Building on these considerations, this chapter reviews the literature on aid effectiveness with a focus to issues specific to fragile states (Section 2). The existing literature on aid and growth has not yet reached a consensus on aid effectiveness, mostly because of severe methodological challenges that complicate the identification of causal effects in macro data. Bringing new evidence is beyond the scope of this chapter, which instead discusses several aspects of aid

\footnotetext{
${ }^{4}$ See: https://www.worldbank.org/en/topic/fragilityconflictviolence/overview\#2 (last accessed: June 2019).
} 
assistance that may affect the effectiveness of aid flows to promote inclusive growth in fragile states.

Then, the chapter presents several stylized facts on aid flows to fragile states, looking both at country-level and sector-level data (Section 3). Plotting aggregate trends in aid flows shows three main features. First, the data highlight the aid dependency of several fragile states, where aid inflows account, in a few cases, for more than 10 percent of GDP. These flows have been declining over time and are not counter-cyclical, suggesting that they cannot really serve as a shock absorber. However, on the bright side the data indicate that aid flows to fragile states have become less unpredictable over time. Third, there is a clear increasing trend in aid fragmentation over time, coupled with a stable share of multilateral aid flows and a recent increase in the share of aid delivered as budget support rather than project aid. Since a large number of donors can overburden the local institutional capacity and result in less efficient spending (Djankov et al. 2009), the recent increase in budget support, maximizing the ownership of aid flows, could mitigate the potentially negative effects of donor fragmentation (Dreher et al. 2018b).

The final part of the chapter takes advantage of project-level data to provide novel evidence on aid effectiveness in fragile states (Section 4). The analysis of a large dataset of aid projects funded by 7 large donors over the period 1980-2012 shows that the success rate of a project is significantly lower in fragile states (and if implemented during a conflict), even after controlling for a large set of country and project specific characteristics, and a granular set of fixed effects which absorb the impact of unobserved factors on differences in the project success rates across sectors and over time. Our results are economically sizable and indicate that a project implemented in a fragile state is about 8 percentage points less likely to be successful than a similar project financed in another developing country.

For a sub-sample of aid projects financed by the World Bank we can extend our analysis at the sub-national level, focusing on the conflict dimension of fragility, and exploiting the variation of conflict within countries and over time. In this case we can strengthen the identification of the effects of (conflict) fragility on aid effectiveness by controlling for country fixed effects, which absorb any cross-country variation that may affect project outcomes. The results indicate 
that the likelihood that a project is successful is lower in conflict (sub-national) regions, further strengthening our argument that aid effectiveness could be weaker in fragile states than in comparable countries. Finally, we find that the project success rate increases with stronger control of corruption, showing that polices targeted at curbing corruption could contribute to increase aid effectiveness.

\section{Aid effectiveness: a brief literature review}

Does aid help countries grow? While the economic literature on foreign aid is extremely broad (see, among others, the seminal contributions by Alesina and Dollar 2000; Boone 1996), it has not yet reached a consensus on whether aid is effective in promoting growth in the recipient country (see, among others, Rajan and Subramanian 2008; Clemens et al. 2012; Dreher and Lohmann 2015; Arndt et al. 2015; Galiani et al. 2017; Dreher et al. 2018a; and Addison et al. 2017 for an overview of the macroeconomics of aid). Existing studies find that the success of aid in boosting the recipient country's economy is conditional on donor characteristics and their motivations (Kilby and Dreher 2010; Dreher et al. 2018a; Minasyan et al. 2016), and on the quality of policies and institutions in recipient countries (see Burnside and Dollar 2000; Collier and Dollar 2002), although the evidence on the importance of sound policies and institutions is far from clear (Easterly et al. 2004). In this section, we briefly review the characteristics of aid flows, donor, and recipient countries which the literature has identified as elements that can influence the effectiveness of aid for economic development. For a comprehensive review of these factors and their role played in countries with limited statehood, see also Dreher et al. (2018b).

A first key element is the notion that large aid inflows can put pressure on the exchange rate, with negative effects on external competitiveness, exports, and manufacturing growth (Arellano et al. 2009; Rajan and Subramanian 2011). Related to this issue, a more general concern is that the capacity to absorb foreign aid is impaired by various types of bottlenecks, implying that there are diminishing returns to aid (Clemens and Radelet 2003; Bourguignon 
and Sundberg 2006; Clemens et al. 2012). ${ }^{5}$ Consistent with this conjecture, the empirical literature at the macro-level shows decreasing marginal returns to aid (Clemens et al. 2012). Focusing on project level data, Presbitero (2016) finds that World Bank investment projects are less likely to be successful if implemented during periods of public investment booms, because of absorptive capacity constraints in recipient countries. Carter (2014) shows that, when recipients face absorption constraints, aid allocations that favor poorer recipients are not always optimal and a sizable portion of aid could be wasted. In line with this evidence, Feeny and McGillivray (2009) show that a number of fragile countries receive more aid inflows than what they can efficiently absorb, with negative effect on the impact of these flows on growth and poverty reduction. On the other hand, and focusing only on the conflict dimension of fragility, Collier and Hoeffler (2004) document that absorptive capacity is greater than normal in post-conflict countries, suggesting that more aid could be channeled to these countries, under the conditions that could policies are in place.

Large inflows are also often associated with a multitude of international agencies, including regional development banks, emerging bilateral donors, global funds, philanthropic foundations, and non-governmental organizations (NGOs). Donor proliferation and aid fragmentation across donors (or sectors) is a second factor that has been largely investigated as potentially harmful for aid effectiveness (see, for instance, Easterly and Pfutze 2008 and Kimura et al. 2012). When aid is fragmented, transaction costs become generally higher (Anderson, 2012; Acharya et al. 2006), and the quality of public sector bureaucracy decreases because of corruption (Djankov et al. 2009; Knack and Rahman, 2007). At the same time, while most of the literature focuses on the negative effect of aid fragmentation, recent studies stress that the participation of several donors and a greater diversity can help developing better policies. Kimura et al. (2012), for instance, use a donor-concentration index to capture a low degree of donor proliferation and find that aid proliferation has a negative effect on the

\footnotetext{
${ }^{5}$ More generally, Besley and Mueller (2019) discuss the role of institutions and state capacity as a key constraint in fragile states. While their focus is on fiscal capacity, the notion that weak state capacity act as bottleneck to raise revenue has similar implications for the capacity to absorb and use effectively aid inflows.
} 
economic growth of recipient countries, especially in Africa. ${ }^{6}$ By contrast, Han and KoenigArchibugi (2015) and Koeln (2019) argue that a larger number of donors can bring a more diverse set of views that in turn can generate better policies. Consistent with this hypothesis, Han and Koenig-Archibugi (2015) find a U-shaped relationship between the number of donors and the effectiveness of health aid, while Koeln (2019) shows that diversity provided by a multitude of donors helps improve a recipient country's democracy. Gehring et al al. (2017) also find that the effects of fragmentation are not universally negative. Rather, they stress significant heterogeneity across sectors and channels of influence, with the so-called "social sectors" benefiting from aid fragmentation and the lack of a lead donor triggering the negative effect.

A third aspect that could mitigate the growth dividend of foreign aid is its unpredictability (and volatility), which could be the consequence of uncoordinated and fragmented donors. Aid unpredictability is generally measured as the deviation of aid commitments from disbursements and captures potential shortfalls in aid flows which could generate pressures on public finances (Celasun and Walliser, 2008; Kodama, 2012). Unpredictable and volatile aid can reduce aid effectiveness (Arellano et al. 2009; Bulir and Hamann 2008) and can have asymmetric negative effects on the level and composition of government expenditures, given that aid shortfalls are likely to reduce investment projects, while windfalls are often spent on consumption rather than investment.

Donors provide aid through the financing of specific projects (project finance) or delivering general support to the recipient country (budget support), imposing conditionality on how the funds are allocated to avoid granting full control to recipient government on how to spend the money. The literature has been long debating the pros and cons of these two different approaches to deliver international aid and have not yet settled on what is preferable. Cordella and Dell'Ariccia (2011) show theoretically that budget support is preferable when the donors' preferences are aligned to those of the recipients and the disbursements are small relative to the recipient country's domestic resources. Similarly, Morrissey (2006) shows that it is safe to

\footnotetext{
${ }^{6}$ Recent evidence by Davies and Klasen (2019) seems to suggest that herding is a key feature of the interaction of donors when making aid allocation choices, so that more coordination could be beneficial and favor the transmission of information.
} 
provide budget support when recipients agree to spend the funds in line with donors' preferences. Eifert and Gelb (2005) favor budget support regardless of governance levels in recipient countries because of lower transaction costs for the donors reducing the number of projects. Gupta et al. (2006), instead, argue that project aid is preferable as it is less volatile than aid channeled through general budget support. More recently, Dreher et al. (2017) argue in favor of budget support aid in democratic countries, since it attributes full responsibility to recipient governments, while project aid generates lower ownership.

Another aspect that is generally recognized as impacting aid effectiveness is whether the funds are allocated through multilateral agencies or bilateral donors. The literature traditionally identifies multilateral aid as being more targeted to support development outcomes, while bilateral aid is seen as linked to donor strategic interests (Alesina and Dollar, 2000; Burnside and Dollar, 2000; Milner and Tingley, 2013). On the other hand, recent studies find evidence suggesting that flows allocated through multilateral agency are also guided by political interests: Dreher et al. (2009), for instance, find that UN Security Council membership influences World Bank loans. A recent meta-analysis by Biscaye et al. (2017) on 45 empirical studies find no consistent evidence that either bilateral or multilateral aid is overall more effective in improving development outcomes.

Finally, several studies also focus on the sectoral allocation of aid and find that ODA are often used for different purposes than those originally decided. For instance, Collier and Hoeffler (2007) and Langlotz and Potrafke (2019) find that aid is correlated with higher military expenses in receiving countries, even though ODA excludes military use. In terms of sectoral allocation, there is also no agreement in the literature on whether foreign aid is more successful in improving outcomes in certain sectors than in others. There is some encouraging evidence that aid disbursed toward the education sector has positive impact (Dreher et al. 2008; Christensen et al. 2011, Birchler and Michaelowa 2016), while there is no conclusive evidence as far as the health is concerned (Williamson 2008, Nunnenkamp and Öhler 2011).

\section{Is Aid in Fragile States Different? Stylized Facts}

What is the role of all the factors discussed in the previous section in fragile states? While the empirical evidence focusing specifically on aid in fragile states is still limited because of data 
limitations (Dreher et al. 2018b), we now turn to the data and investigate how the characteristics of aid flows differ between fragile and non-fragile states to try to understand which factors are more likely to undermine aid effectiveness in fragile states. ${ }^{7}$ The following analysis is predominately based on OECD DAC data.

Fragile countries receive about three-times more aid as a share of their GDP than non-fragile states that receive DAC ODA flows. A first inspection of the aggregate data since 1990 reveals that fragile states are highly dependent on foreign assistance. Considering countries with complete aggregate data on net ODA (in percent of GDP) over the period 1990-2017 and comparing 25 fragile states with 75 low- and middle-income countries shows that, on average, net ODA account for almost 15 percent of GDP in fragile states, while the average ODA-toGDP ratio is 6 percent in the other countries (Figure 1). ${ }^{8}$ Zooming in at the country level reveals significant heterogeneity in degree of exposure to aid. Afghanistan and Liberia exhibit the highest levels of ODA to GDP, followed by Burundi, West Bank and Gaza Strip, Eritrea and Somalia (Figure 2). All the fragile countries, except Libya, Angola and Myanmar received more aid (as a ratio to GDP) than the median levels for non-fragile countries. ${ }^{9}$

Aid dependency is also evident when comparing net ODA inflows with two other key sources of external financing, remittance inflows and net foreign direct investment. While, in the broad sample of low- and middle-income countries, remittances and FDI are the two major sources

\footnotetext{
${ }^{7}$ We use the definition of fragile states from the IMF Independent Evaluation Office (IEO) (IMF 2018). For the complete list see https://www.imf.org/en/Publications/Policy-Papers/Issues/2017/06/14/pp041817buildingfiscal-capacity-in-fragile-state (page 45). The countries considered are: Afghanistan, Angola, Bosnia and Herzegovina, Iraq, Burundi, Central African Republic, Chad, Comoros, Congo Democratic Republic, Eritrea, Guinea, Guinea-Bissau, Haiti, Kiribati, Kosovo, Liberia , Libya , Madagascar, Malawi, Mali, Marshall Islands, Tuvalu, Micronesia, Myanmar, Nepal, Congo Republic of, Côte d'Ivoire, São Tomé and Príncipe, Solomon Islands, Sudan, Sierra Leone, Somalia, South Sudan, Syria, Timor-Leste, Togo, West Bank and Gaza, Yemen, Zimbabwe. We exclude countries with population less than 1 million.

${ }^{8}$ The median values are, respectively, 9.8 and 3.2 percent. A caveat to keep in mind when working on low-income countries is data quality, which could be weakened by limited funding and weak capacity of local statistical agencies (Devarajan, 2013; Klasen and Blades, 2013).

${ }^{9}$ Discussing the reasons behind aid allocations, especially to fragile states, by donors is beyond the scope of this chapter. For a review of donors' motives, including geo-political interests, see Alesina and Dollar (2000), Berthelemy (2006) and Fuchs et al. (2014).
} 
of foreign exchange earnings (World Bank 2018), in fragile states aid inflows are still much larger than remittances and FDI (Figure 3).

Other than aid volumes, the literature on aid effectiveness points out the importance of volatility, cyclicality and predictability of aid inflows. Contrary to a common perception, aid flows in fragile states are not more volatile than in other developing countries (the average coefficient of variation is 0.64 in fragile states and 0.74 in the other developing countries). ${ }^{10}$ While year-on-year changes could have a number of adverse consequences on macroeconomic management, aid volatility is not necessarily a bad thing. Especially for countries exposed to a large variety of shocks, one would expect a high volatility if aid is able to respond to negative economic shocks. For this reason, looking at aid cyclicality can provide a better measure of the capacity of aid to mitigate negative shocks. A simple inspection of the macroeconomic data shows that aid to developing countries is, on average, moderately counter-cyclical. However, the negative correlation between aid as a share of GDP and the cyclical component of GDP is driven mostly by non-fragile states, while it is very close to zero for fragile states. ${ }^{11}$ Overall, the macro data suggest that aid inflows have a limited capacity to act as a shock absorber in developing countries, but less in fragile states. Finally, we consider aid unpredictability, which can have adverse effects on the level and the composition of government spending, undermining aid effectiveness and jeopardizing growth. This could be especially the case for fragile states which often lack access to international capital markets and have limited foreign reserves to serve as buffers. Figure 4 shows the evolution over time of a standard proxy for aid unpredictability, the difference between commitments and disbursements, both measured as a share of GDP. At the beginning of the sample fragile countries presented significantly higher level of unpredictable aid (almost double) than non-fragile countries. However, there is a marked downward trend throughout the sample for both country groups, suggesting improvements in the predictability of flows across all recipients.

\footnotetext{
${ }^{10}$ The median values are, respectively, 0.64 and 0.55 .

${ }^{11}$ The cyclical component of GDP is computed using the Hodrick-Prescott (HP) filter to the annual series of the logarithm of real GDP. The correlation between this cyclical GDP component and aid (as a share of GDP) is equal to -0.15 for non-fragile developing countries and -0.03 for fragile states. The sample includes 23 fragile states with 74 low- and middle-income countries with full data on aid and real GDP between 1990 and 2017.
} 
Moving to the granularity of aid inflows, we start by investigating the degree of aid fragmentation across donors in our sample. We follow Gehring et al. (2017) and build two different measures of fragmentation. First, we build the Herfindahl index of aid concentration across donors in each country over time:

$$
H I_{c t}=\sum_{d=1}^{D} \operatorname{share} e_{d c t}^{2}
$$

where $\mathrm{d}=1, \ldots, \mathrm{D}$ are donors and share ${ }_{d c t}^{2}$ is the share of disbursements from donor $d$ in recipient country $c$ in year $t$. We compute fragmentation as $1-H I_{c t}$. The second proxy for fragmentation is the number of donors per country. We observe an increasing degree of fragmentation in fragile states since the beginning of the 1990s, with the fragmentation index flattening at the beginning of the 2000s (Figure 5). This trend is similar to the one observed in the rest of ODA recipients, that present a comparable number of donors, with the median being 33 across the sample considered. In sum, the rising trend in donor fragmentation indicates another potential source of concern for aid effectiveness in fragile states. Related to this issue, we observe that the bulk of ODA is delivered by bilateral donors and there is no upward trend in the share of multilateral aid, which would be consistent with a change in aid allocationspecifically targeted towards fragile states - by multilateral agencies. In our sample, on average since the 2000s, both non-fragile and fragile countries received about 70 to 80 percent of total disbursements through bilateral flows.

A final important aspect to consider when moving beyond aid aggregates is the sectoral composition of aid and its type. In our sample of fragile states, the three largest recipient sectors are the government, action related to debt (aid for debt relief/restructuring, reflecting the bilateral and multilateral debt relief initiatives of the mid-1990s and early 2000s - see Arnone and Presbitero (2009) for an overview) and emergency response (Figure 6), consistent with the vulnerability of fragile states to external shocks. When looking at aid type, we focus on budget support, as a measure of how much aid is given directly to the government, to increase ownership. Budget support flows are also less volatile than other aid flows. ${ }^{12}$ The share of

\footnotetext{
${ }^{12}$ The average coefficient of variation for budget support aid in fragile countries is 2 , while is non-fragile states is 7 .
} 
budget support disbursements over total disbursements in fragile states shows a steep decline in the late 1990s and a recent pick-up in the mid-2000s (Figure 7, see also Dreher et al. 2017). On the contrary, non-fragile DAC countries present steadily decreasing budget support flows. The recent increase in the share of total disbursements in budget support in fragile states might come as a surprise, as donors tend to trust less governments in fragile states (see Dreher et al. 2018b). ${ }^{13}$ However, looking at the channels of delivery, Dreher et al. (2018b) find that less aid is allocated through governments in fragile states.

Overall, our reading of the literature and of the evidence on aid effectiveness in fragile states suggest that the growth dividend of aid flows could be limited by a number of factors (e.g., high aid dependency coupled with limited absorptive capacity, limited propensity to act as a shock absorber, rising donor fragmentation), which are common to several recipients, but are often more prevalent in fragile states. This does not imply that aid to fragile states should be reduced across the board (Dreher et al. 2018b). By contrast, this evidence would point to an approach tailored at targeting the key bottlenecks to promote aid effectiveness. First, non-aidspecific policies directed at promoting state building and stability would also contribute to better aid effectiveness. Then, aid polices should consider the extent to which absorptive capacity constraints, lack of donor coordination, aid unpredictability, or the modalities of aid delivery (budget support vs project aid, for instance) act as a major constraint to aid effectiveness.

\section{Aid Effectiveness: Project-level Analysis}

Overall, the literature on aid effectiveness, reviewed in Section 2, does not provide a clear answer on the extent to which aid can promote growth in fragile states. Similarly, the set of stylized facts discussed in Section 3 shows conflicting trends: aid flows are large, but their effectiveness could be weakened by absorptive capacity constraints, aid dependency, and donor fragmentation. Thus, in this section we look explicitly at aid effectiveness in fragile states, by exploiting a large dataset on project-level data which brings together other 14,000

\footnotetext{
${ }^{13}$ Dreher et al. (2018b) adopt a different fragile states classification that includes 19 countries.
} 
projects funded by 8 donor agencies ${ }^{14}$ in 176 countries approved since 1956 until 2012 (Honig 2018). For each project, the data collects information on the dates of approval, completion and evaluation; the sector of the project; the presence of the funding donor in the country with an office; and, most importantly, the rating of the project's overall success, measured on a scale from 1 (highly unsatisfactory) to 6 (highly satisfactory). ${ }^{15}$ Then, depending on the donor, other project-specific information is available, including the lending instrument and the project cost, in case of World Bank's projects.

Figure 8 shows the distribution across countries of the average share of successful projects. The map clearly points out the relatively poorer performance in many sub-Saharan African countries compared to countries in Eastern Europe and Asia. The distribution of successful projects across fragile and non-fragile states indicates that projects undertaken in fragile states are less likely to be successful, with a large share of countries below the 50 percent success rate (Figure 9). As the observable project characteristics do not appear to be systematically different between projects undertaken in fragile and non-fragile states (see Table 1), differences in project success rates are likely to be driven by country characteristics (e.g., fragility).

The availability of project-level data with information on project's outcome allows to directly test whether the success rate in fragile states is significantly different than in other countries, controlling for a set of project-specific characteristics and a variety of granular fixed effects, which absorb unobserved heterogeneity. To run this exercise, we estimate the following linear model, which is similar in spirit to existing works done by Denizer et al. (2013) and Presbitero (2016) in a similar context:

\footnotetext{
${ }^{14}$ The Asian Development Bank, the UK's Department for International Development, the Global Fund for AIDS, TB, and Malaria, the German Society for International Cooperation (GiZ), the International Fund for Agricultural Development, the Japanese International Cooperation Agency, the German Development Bank (KfW), and the World Bank.

${ }^{15}$ Following Presbitero (2016), Bulman et al. (2015) and Kilby (2015), we classify a project as successful if it has been evaluated as "highly satisfactory", "satisfactory" or "moderately satisfactory" and as unsuccessful if it has been evaluated as "moderately unsatisfactory", "unsatisfactory" or "highly unsatisfactory". In line with existing literature (Deninzer et al. 2013; Presbitero 2016), in the case of a 0/1 dependent variable we estimate a linear probability model, which can more flexibly accommodate a large set of granular fixed effects than a probit model. See also Briggs (2019) for a recent analysis of aid success using these data.
} 


$$
\text { OUTCOME }_{i j t}=\beta F S_{j}+\delta \text { Country }_{j t}+\gamma \text { Project }_{i j t}+\varepsilon_{i j t}
$$

where the dependent variable $O U T C O M E_{i j t}$ is, alternatively, the rating of project $i$ undertaken in country $j$ at time $t$, measured on the 1 to 6 scale, or by a dummy equal to one if the investment project is evaluated as satisfactory and zero otherwise. The key explanatory variable is $F S_{j}$, a dummy equal to one for fragile states, defined according to the IMF classification. Since the FS dummy does not vary over time and we cannot include country fixed effects, we control for a set of macroeconomic variables which should absorb cross-country heterogeneity and add region and income-level fixed effects. ${ }^{16}$ The set of country-specific variables (Country $y_{j t}$ ) includes the logarithm of real per capita GDP, the growth rate and the variability of real GDP, and the ratios of foreign aid and private capital inflows over GDP. Country-specific variables are measured as averages over the length of the project, computed as the difference between the completion and the start year. The vector of project-specific characteristics (Project $_{i j t}$ ) includes: 1) the duration of the projects, measured (in years) as difference between date of project completion and date of project start;2) the lag to project evaluation, measured (in years) as difference between date of project evaluation and date of project completion; and 3) a dummy to identify projects for which the donor agency had an office in the country during the length of the project. We also include donor fixed effects to allow for donor-specific unobserved differences in project evaluation. Fixed effects for the start and evaluation years and a set of 36 sector fixed effects, based on 3-digit purpose classification code used by the Creditor Reporting System (CRS) of the OECD-DAC, absorb sector-specific and time-specific unobservable differences in project outcomes. In the most demanding specification, we introduce sector x evaluation year and sector x start year fixed effects, to control for external (sector-specific) aggregate shocks and unobservable changes in the evaluation standards over time. We cluster the standard errors at the country level to allow for the potential correlation of the residuals within country.

\footnotetext{
${ }^{16}$ We follow the World Bank classification and we include: 6 regional dummies for East Asia \& Pacific, Europe \& Central Asia, Latin America \& Caribbean, Middle East \& North Africa, South Asia, and Sub-Saharan Africa; and 4 income-level dummies for high income, upper middle income, lower middle income and low-income countries.
} 
Results show that the fragile state dummy is consistently associated with a lower probability of project success (Table 2). This is true for the full sample that includes all donors and the sample restricted to World Bank projects; in this case we can also control for project sizeproxied by the logarithm of the project cost (in US dollar). To quantify the economic magnitude of this correlation, our findings indicate that, on average, the rating of a project in a fragile state is 0.2 points lower than a similar one in non-fragile countries (column 2). When considering the dummy variable for successful projects, our results indicate that a project carried out in FS is 8 percentage points less likely of being successful than a similar one in non-fragile developing countries (column 4). Given that the average in-sample success rate is 73 percent, this effect is relatively large. ${ }^{17}$

The volatility of growth has also a negative effect on the likelihood of project success, while overall GDP growth is associated with positive outcomes. Consistent with the evidence presented in Presbitero (2016), Kilby (2015), and Denizer et al. (2013), projects are more likely to be successful when they are undertaken during periods of higher growth rates at the countrylevel. Other macro variables (non-reported in the table) such as overall aid to GDP, net capital flows as a percent of GDP, and GDP per capita are not playing a significant role in explaining project success in our sample. We also do not find significant evidence that project duration, its cost, the presence of a local office, and the time needed to evaluate the project matter for the probability of a successful projects after controlling for a large set of fixed effects. ${ }^{18}$

\subsection{The Conflict Dimension of Fragility}

The analysis presented in Table 2 confirms that, even controlling for project and country factors and a large set of fixed effects, investment projects are less likely to be successful when carried out in fragile states than elsewhere. However, even controlling for several macroeconomic variables does not exclude that this correlation could be due to a number of unobservable country characteristics that are different between fragile and other developing

\footnotetext{
${ }^{17}$ The summary statistics show that the difference in the success rate between fragile (61 percent) and non-fragile (74 percent) states is 13 percentage points.

${ }^{18}$ Denizer et al. (2013) and Presbitero (2016) find mixed evidence on the correlation between the proxies for project complexity and outcomes: smaller projects are generally more likely to be successful than larger (i.e. more complex) ones, but these results lose significance we country fixed effects are included in the estimation.
} 
countries. In other words, the $F S_{j}$ dummy could capture several unobserved country characteristics, other than fragility, which may explain differences in the likelihood of project success. To overcome this concern, we focus on the conflict dimension of fragility and we run two additional exercises, which exploit the variation of conflicts over time and within countries.

First, we modify model (1) replacing the time-invariant $F S_{j}$ dummy with a time-varying indicator of the presence of a conflict in country $j$ at time $t$ (Conflict (jt $):{ }^{19}$

$$
\text { OUTCOME }_{i j t}=\beta \text { Conflict }_{j t}+\text { SCountry }_{j t}+\gamma \text { Project }_{i j t}+\psi_{j}+\varepsilon_{i j t}
$$

In this way we can augment the model with country fixed effects $\left(\psi_{j}\right)$ and estimate the effect of a conflict on the likelihood of project success within-country (and also controlling for timevarying sector specific shocks).

The results - reported in Table 3 - are consistent with our baseline and show that the likelihood that a project is successful is lower in conflict periods, even after controlling for any timeinvariant dimension of country fragility, project characteristics and time-varying sectorspecific unobservable heterogeneity. The economic size of the reduction of the project rating is similar to what discussed in the baseline (Table 2), while the likelihood of project success is 4.8 percentage points lower in conflict years than in tranquil periods (column 4).

Second, we take advantage of georeferenced data on World Bank investment projects and conflicts and we zoom in on the role played by conflicts at the sub-national level. ${ }^{20} \mathrm{We}$ rely on the data collected by Gehring et al. (2019), which provide information on whether an ADM2 region in a certain year experienced a conflict, and on AidData for the geocoded World Bank

\footnotetext{
${ }^{19}$ The indicator variable Conflict $_{j t}$ equals to one if during the length of the project the country experienced a war conflict defined as causing at least 1000 battle-related deaths in one calendar year (Intensity level=2).

${ }^{20}$ The literature on aid and conflict progressively used georeferenced data to investigate subnational dynamics. In a recent paper, Gehring et al. (2019) aims at bridging the gap between analyses at the country level and specific country studies using more disaggregated data. They combine information on georeferenced projects by the World Bank and China and conflicts data at the regional level based on the Uppsala Conflict Data Program's (UCDP) georeferenced event dataset (Sundberg and Melander, 2013; Croicu and Sundberg, 2015). Their findings suggest that there is no systematic evidence that aid triggers conflict at the regional level. On the contrary, they support the fact that aid reduces the probability of lethal actions by the state and in particular in the transport sector.
} 
projects. ${ }^{21}$ To maximize coverage, in the empirical analysis we collapse the conflict data at the ADM1 level and we restrict the data to all the ADM1 regions where a World Bank project is recorded. The empirical model is similar to equation (1) with the difference that the dependent variable OUTCOME $E_{\text {irjt }}$ measures the outcome of the project $i$ undertaken in the ADM1 region $r$ of country $j$ at time $t$ :

$$
\text { OUTCOME }_{\text {irjt }}=\beta \text { Conflict }_{\text {irjt }}+\text { SCountry }_{j t}+\gamma \text { Project }_{\text {irjt }}+\varepsilon_{\text {irjt }}
$$

The key explanatory variable - Conflict ${ }_{r j t}$-is a dummy equal to one if a region $r$ experiences at least one conflict in a given year. Given that the conflict dummy varies by region and time, we can again augment the estimation with country fixed effects, to absorb all those timeinvariant characteristics that might make fragile countries different. In addition, we can also saturate the model with ADM1 region fixed effects, and exploit only the within region variation over time of conflicts and World Bank projects. The set of control variables at the country- and project-level are the same as in equation (1). As we focus on World Bank projects, we can also control for project size as in Table 2 (columns 5-8).

The results are reported in Table 4 and confirm that fragility is associated with a lower project success rate, notwithstanding the significant reduction in sample size and the more demanding empirical design. The coefficient on the regional conflict dummy is negative, but not significant, when we measure project success with the continuous rating variable (columns 12). However, it becomes statistically significant when project success is measured by the dummy indicator (columns 3-4). The economic magnitudes are comparable to what we found in the previous exercises. The model of column 3 with country fixed effects indicates that a project is 5.3 percentage points less likely of being successful if it has been implemented in a conflict region than a similar project in the same country (but implemented in a non-conflict region). The specification with region fixed effects shows that a project in a conflict region is 6.4 percentage points less likely of being successful than a similar project in the same region but started in a non-conflict year (column 4).

\footnotetext{
${ }^{21}$ A conflict is defined as an event in which there are more than 25 casualties: see Gehring et al. (2019) for further details. ADM1 corresponds to the first level of sub-national administrative division ("provinces", "states", or "regions"). ADM2 corresponds to lower level administrative regions.
} 


\subsection{The Role of Corruption}

The evidence discussed in the previous sections clearly indicates that aid is likely to be less effective in fragile states than in other developing countries, with conflict being a key element that could reduce projects' success rate. However, state fragility is a multidimensional concept (IMF 2018; OECD 2018) and aid effectiveness could be improved implementing policies along many dimensions. Since it is oftentimes difficult to map policies into outcomes in a rigorous setting, here we limit our attention to the role of corruption, which we can measure in a precise way through the World Governance Indicators. In particular, "control of corruption captures perceptions of the extent to which public power is exercised for private gain, including both petty and grand forms of corruption, as well as "capture" of the state by elites and private interests" (Kaufmann et el. 2010).

As the number of fragile states is too low to rigorously investigate the effect of corruption on aid effectiveness across fragile and non-fragile states, we look at the association between corruption and project success in the whole sample of developing countries. We estimate equation (1) on a sub-sample of country-year pairs for which we can match our data with the control of corruption variable. ${ }^{22}$ Notwithstanding the small sample and the rich set of fixed effects, the results - reported in Table 5-show a clear and positive association between the strength of the control of corruption and project success. In economic terms, the most conservative estimates show that one standard deviation change in the control of corruption index (equal to 1 , as the variable is standardized) is associated with 0.15 increase in project rating (column 2) and with 6 percentage point increase in the likelihood of project success (column 4). In the spirit of Dreher et al. (2018b), we combine this information with the observation that the control of corruption is weaker in fragile than in other developing countries (Figure 10) to argue that investing in policies to curbing corruption is likely to improve aid effectiveness in fragile states. ${ }^{23}$

\footnotetext{
${ }^{22}$ We end up with a sample that starts in 1996 of 121 countries, only 24 of which are fragile states.

${ }^{23}$ Figure 11 reports the distribution of the variable control of corruption for the two groups, showing higher level of control in non-fragile countries. A t-test on the difference of the means suggests that the average level of corruption in fragile states is significantly lower than in non-fragile states.
} 


\section{Conclusions and Policy Discussion}

Aid dependency is a feature of several fragile states, where aid inflows account, in a few cases, for more than 10 percent of GDP. Can these flows promote growth and development? Methodological issues severely limit our capacity to answer this question, especially when looking at macro data and when zooming in on a relatively small sample of fragile states. Also for this reason, the literature on aid effectiveness has not yet reached a consensus, as results often depends on several concurring factors, ranging from the type of aid flows, donors' policies, and recipient countries' institutional and macroeconomic characteristics.

In a recent survey on aid effectiveness in fragile states, Dreher et al. (2018b) overcome these limitations by combining information on how different types of aid, motives for granting it, recipient country policies and characteristics, and modalities by which aid is delivered shape aid effectiveness with differences of these characteristics across fragile and non-fragile states to conclude that, on average, aid given to fragile states is less likely to be effective than elsewhere.

We confirm this conclusion looking at a large sample of investment projects and showing that a project implemented in a fragile state is about 8 percentage points less likely to be successful than a similar project financed in another developing country. While we are not able to identify the effect of fragility on aid effectiveness, using project-level data allows us to control for a large set of observable and (time-varying) unobservable characteristics which could be correlated with fragility and affect project outcomes. We also focus on the conflict dimension of fragility to further substantiate our conclusion at a sub-national level.

On the policy side, we concur with Dreher et al. (2018b) that our analyses do not imply that aid to fragile states should be reduced across the board. It could be the case that in specific cases, absorptive capacity constraints bind and weaken aid effectiveness. In other cases, lack of donor coordination, aid unpredictability, or the modalities of aid delivery (budget support vs project aid, for instance) could be the most important factor hampering the growth dividend of aid flows, although, on average, some of these factors do not seem to be specific to fragile states. One aspect that seems to be particularly important for project outcomes is corruption, an area where fragile states, on average, look weaker. However, more research - and more granular data - are needed to better identify the constraints to aid effectiveness and inform 
policy making, not only in fragile states. For the time being, aid polices and aid projects in fragile states should be carefully tailored around the large set of country-specific factors that are likely to undermine aid effectiveness. At the same time, given limited aid effectiveness, policies for fragile states should more generally be directed at building the support structurethe scaffolding, in the words of Collier (2019) — which is the key condition to build an effective state. Keeping in mind the challenges of engineering appropriate strategies to promote stability and escape state fragility (see Acemoglu and Robinson 2019), institutions and state buildingas discussed extensively by Besley and Mueller (2019) in this book - can then contribute to mitigate fragility and generate growth through several channels (e.g., enhanced revenue mobilization, better governance, less political instability), including stronger aid effectiveness, thanks to better absorptive capacity, more accountability and less corruption. 


\section{References}

Acemoglu, Daron and James A. Robinson (2019). The Narrow Corridor, New York: Penguin.

Acharya, Arnab, Ana Teresa Fuzzo de Lima and Mick Moore (2006). Proliferation and fragmentation:

Transactions costs and the value of aid. The Journal of Development Studies, 42 (1), 1-21.

Addison, Tony, Oliver Morrissey and Finn Tarp (2017). The Macroeconomics of Aid: Overview, Journal of Development Studies, 53(7): 987-997.

Alesina, Alberto and David Dollar (2000). Who Gives Foreign Aid to Whom and Why?, Journal of Economic Growth, 5(1): 33-63.

Anderson, Edward (2012). Aid fragmentation and donor transaction costs, Economics Letters, 117 (3), $799-802$.

Arellano, Cristina, Ales Bulir, Timothy Lane and Leslie Lipschitz (2009). The dynamic implications of foreign aid and its variability, Journal of Development Economics, 88(1): 87-102.

Arndt, Channing, Sam Jones and Finn Tarp (2015). What is the Aggregate Rate of Return of Foreign Aid?, World Bank Economic Review, 30(3): 446-474.

Arnone, Marco and Andrea F. Presbitero (2010). Debt Relief Initiatives. Policy Design and Outcomes, Ashgate.

Berthelemy, Jean-Claude (2006). Bilateral Donors' Interest vs. Recipients' Development Motives in Aid Allocation: Do All Donors Behave the Same?, Review of Development Economics, 10(2): 179-194. Besley, Timothy and Hannes Mueller (2019). Fiscal Capacity and State Fragility. In R. Chami, R. Espinoza and P. Montiel (eds.), Macroeconomic Policy in Fragile States, Oxford: Oxford University Press.

Birchler, Kassandra and Katharina Michaelowa (2016), Making aid work for education in developing countries: An analysis of aid effectiveness for primary education coverage and quality, International Journal of Educational Development, 48:37-52.

Boone, Peter (1996). Politics and the effectiveness of foreign aid, European Economic Review, 40(2): 289-329.

Bourguignon Francois and Mark Sundberg (2007), Aid Effectiveness - Opening the Black box, American Economic Review, Vol.97(2):316-321. 
Bulír, Aleš and A. Javier Hamann (2008), Volatility of Development Aid: From the Frying Pan into the Fire? World Development, 36(10):2048-2066.

Biscaye, Pierre E., Travis W. Reynolds and C. Leigh Anderson (2016), Relative Effectiveness of Bilateral and Multilateral Aid on Development Outcomes, Review of Development Economics, 21(4):1425-1447.

Briggs, Ryan C. (2019). Results from single-donor analyses of project aid success seem to generalize pretty well across donors, Review of International Organizations, forthcoming.

Bulman, David, Walter Kolkma and Aart Kraay (2017). Good countries or good projects? Comparing macro and micro correlates of World Bank and Asian Development Bank project performance, The Review of International Organizations, 12(3): 335-363

Burnside, Craig and David Dollar (2000), Aid, Policies, and Growth, American Economic Review, 90: 847-868.

Carter, Patrick. (2014). Aid allocation rules. European Economic Review, 71, 132-151.

Celasun, Oya and Jan Walliser (2008). Predictability of Aid, Economic Policy, 23(55): pp.545-594.

Christensen, Zachary, Homer Dustin, and Daniel L. Nielson, 2011. Dodging adverse selection: how donor type and governance condition aid's effects on school enrollment, World Development, 39 (11), 2044-2053.

Clemens, Michael A. and Steven Radelet (2003). Absorptive capacity: how much is too much? In S. Radelet (ed.), Challenging Foreign Aid: A Policymaker's Guide to the Millennium Challenge Account, Washington, DC: Center for Global Development.

Clemens, Michael A., Steven Radelet, Rikhil R. Bhavnani, and Samuel Bazzi (2012). Counting chickens when they hatch: timing and the effects of aid on growth, The Economic Journal, 122, 590617.

Collier Paul and Anke Hoeffler (2004). Aid, policy and growth in post-conflict societies, European Economic Review, 48(5): 1125-1145.

Collier Paul and Anke Hoeffler (2007). Unintended Consequences: Does Aid Promote Arms Races?, Oxford Bulletin of Economics and Statistics, 69(1): 1-27. 
Collier, Paul (2019). Transition Programs: A Theory of the Scaffolding Needed to Build out of Fragility. In R. Chami, R. Espinoza and P. Montiel (eds.), Macroeconomic Policy in Fragile States, Oxford: Oxford University Press.

Commission on State Fragility, Growth and Development (2018). Escaping the fragility trap, London. Cordella, Tito and Giovanni Dell'Ariccia (2007), Budget Support Versus Project Aid, The Economic Journal, 117(523): pp.1260-1279.

Croicu, Mihai and Ralph Sundberg (2015), UCDP Georeferenced Event Dataset Codebook Version 4.0.

D'Alelio, Drew (2018). US Aid to Fragile States: Where Does the Money Go?, Center for Global Development, June 11.

Davies, Ronald B. and Stephan Klasen (2019). Darlings and Orphans: Interactions across Donors in International Aid, The Scandinavian Journal of Economics, 121(1): 243-277.

Denizer, Cevdet, Daniel Kaufmann and Aart Kraay (2013). Good countries or good projects? Macro and micro corelates of World Bank project performance, Journal of Development Economics, 105: 288302.

Devarajan, Shanta (2013). Africa's Statistical Tragedy, Review of Income and Wealth, 59(S1):S9-S15.

DFID (2015). UK aid: Tackling global challenges in the national interest, Department for International Development and HM Treasury.

Djankov, Simeon, Jose G. Montalvo and Marta Reynal-Querol (2009). Aid with multiple personalities. J. Comp. Econ. 37 (2), 217-229.

Dreher, Axel, Peter Nunnenkamp and Rainer Thiele (2008). Does Aid for Education Educate Children? Evidence from Panel Data, World Bank Economic Review, 22(2): 291-314.

Dreher, Axel Jan-Egbert Sturm and James Raymond Vreeland (2009), Development aid and international politics: Does Membership on the UN Security Council Influence World Bank Decisions? Journal of Development Economics, 88(1):1-18.

Dreher, Axel and Steffen Lohmann (2015). Aid and Growth at the Regional Level, Oxford Review of Economic Policy, 31: 420-446. 
Dreher, Axel, Sarah Langlotz and Silvia Marchesi (2017), Information transmission and ownership consolidation in aid programs, Economic Inquiry, 55: 1671-88.

Dreher, Axel, Vera Eichenauer and Kai Gehring (2018a). Geopolitics, Aid and Growth: The Impact of UN Security Council Membership on the Effectiveness of Aid, World Bank Economic Review, 32: 268286.

Dreher, Axel, Valentin Lang and Sebastian Ziaja (2018b). Foreign Aid, in Risse, Thomas, Tanja Börzel and Anke Draude (eds.), The Oxford Handbook on Governance and Limited Statehood, Oxford: Oxford University Press.

Easterly, William, Ross Levine and David Roodman (2004). Aid, Policies, and Growth: A Comment, American Economic Review, 94(3): 774-780.

Easterly, William and Tobias Pfutze (2008). Where does the money go? Best and worst practices in foreign aid. Journal of Economic Perspectives, 22 (2), 29-52.

Feeny, Simon and Marck McGillivray (2009). Aid allocation to fragile states: Absorptive capacity constraints, Journal of International Development, 21(5): 618-632.

Fuchs, Andreas, Axel Dreher and Peter Nunnenkamp (2014). Determinants of Donor Generosity: A Survey of the Aid Budget Literature, World Development, 56: 172-199.

Galiani, Sebastian, Stephen Knack, Lixin Xu and Ben Zou (2017). The effect of aid on growth: evidence from a Quasi-experiment, Journal of Economic Growth, 2017, vol. 22, issue 1, 1-33.

Gehring, Kai, Katharina Michaelowa, Axel Dreher and Franziska Sporri (2017). Aid Fragmentation and Effectiveness, World Development, 99: 320-334.

Gehring, Kai, Lennart Kaplan and Melvin Wong (2019). Aid and Conflict at the Subnational Level Evidence from World Bank and Chinese Development Projects in Africa, AidData Working Paper 70. Gupta, Sanjeev, Pattillo Catherine and Smita Wagh (2006), Are Donor Countries Giving More or Less Aid? Review of Development Economics, 10(3): 535-552.

Han, Lu and Mathias Koenig-Archibugi (2015). Aid Fragmentation or Aid Pluralism? The Effect of Multiple Donors on Child Survival in Developing Countries, 1990-2010, World Development, 76: 334358.

Honig, Dan (2019). Navigation by Judgment: Why and When Top Down Management of Foreign Aid Won't Work. New York: Oxford University Press. 
IMF (2012). Malawi: 2012 Article IV Consultation and Request for a New Arrangement Under the Extended Credit Facility, IMF Country Report No. 12/221.

IMF (2017). Building Fiscal Capacity in Fragile States, Policy Paper, International Monetary Fund.

IMF (2018). The IMF and Fragile States, Independent Evaluation Office, International Monetary Fund. Kaufmann, Daniel, Aart Kraay and Massimo Mastruzzi (2010). The Worldwide Governance Indicators: Methodology and Analytical Issues, World Bank Policy Research Working Paper, No. 5430.

Kodama, Masahiro (2012): “Aid Unpredictability and Economic Growth,” World Development, 40(2), $266-272$.

Kilby, Christopher and Axel Dreher (2010). The impact of aid on growth revisited: Do donor motives matter?, Economics Letters, 107(3): 338-340.

Kilby, Christopher (2015). Assessing the impact of World Bank preparation on project outcomes, Journal of Development Economics, 115: 111-123.

Kimura, Hidemi, Yuko Mori and Yasuyuki Sawada (2012). Aid Proliferation and Economic Growth: A Cross-Country Analysis, World Development, 40(1): 1-10.

Klasen, Stephan and Derek Blades (2013). Issues and Challenges in Measuring National Income, Wealth, Poverty, and Inequality in Sub-Saharan African Countries: An Introduction, Review of Income and Wealth, 59(S1):S1-S8

Knack, Stephen and Rahman Aminur (2007). Donor fragmentation and bureaucratic quality in aid recipients. Journal of Development Economics, 83 (1), 176-197.

Langlotz, Sarah and Niklas Potrafke (2019). Does development aid increase military expenditure?, Journal of Comparative Economics, forthcoming.

Minasyan, Anna, Peter Nunnenkamp and Katharina Richert (2017). Does Aid Effectiveness Depend on the Quality of Donors?, World Development, 100:16-30.

Nunnenkamp, Peter and Hannes Öhler (2011). Throwing Foreign Aid at HIV/AIDS in Developing Countries: Missing the Target?, World Development, 39(10):1704-1723.

OECD (2018). States of Fragility, http://www.oecd.org/dac/states-of-fragility-2018-9789264302075en.htm 
Presbitero, Andrea (2016). Too much and too fast? Public investment scaling-up and absorptive capacity, Journal of Development Economics, 120: 17-31.

Rajan, Raghuram and Arvind Subramanian (2008). Aid and Growth, Review of Economics and Statistics 90(4): 643-665.

Rajan, Raghuram and Arvind Subramanian (2011). Aid, Dutch Disease, and Manufacturing Growth, Journal of Development Economics, 94(1): 106-118.

Sundberg, Ralph and Erik Melander, 2013. Introducing the UCDP Georeferenced Event Dataset, Journal of Peace Research, 50(4) 523-532.

World Bank (2018). Migration and Remittances—Recent Developments and Outlook, Migration and Development Brief.

Williamson, Claudia (2008), Foreign Aid and Human Development: The Impact of Foreign Aid to the Health Sector, Southern Economic Journal, 75(1):188-207.

Wroe, Daniel (2012). Donors, dependency, and political crisis in Malawi, African Affairs, 111(442): 135-144. 


\section{Figures}

Figure 1. Median ODA over time (percent of GDP)

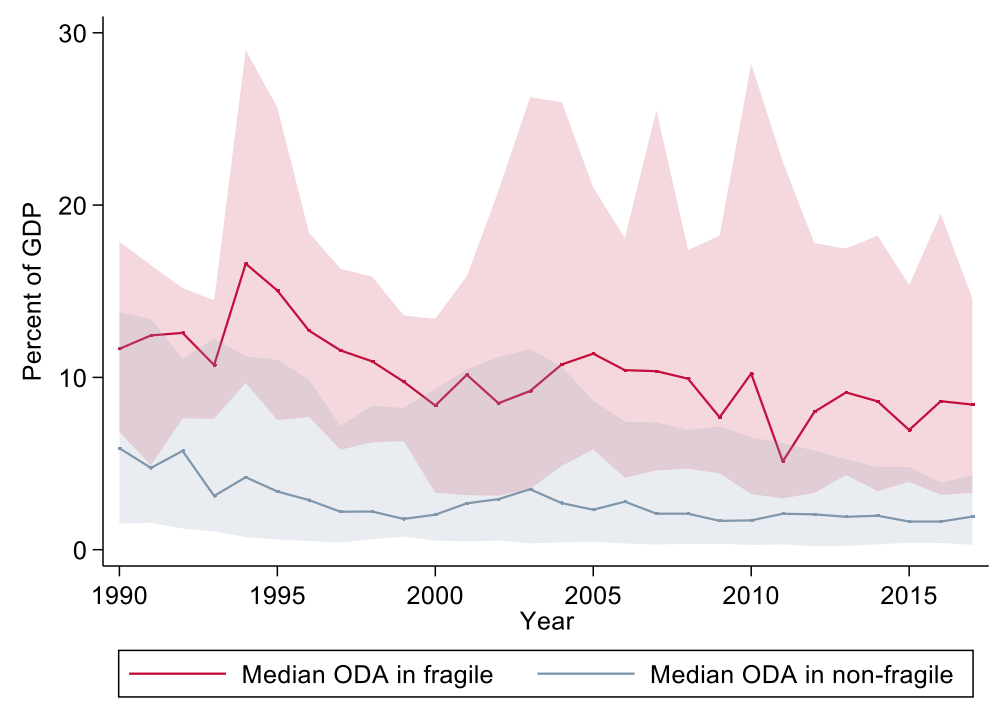

Notes: the chart reports the median net official development assistance received over GDP from the World Bank World Development Indicators over the sample 1990 to 2018 . The shaded areas correspond to the $25^{\text {th }}$ and $75^{\text {th }}$ percentiles. We exclude countries with population less than 1 million. See text for the sample of countries.

Figure 2. ODA to GDP by country

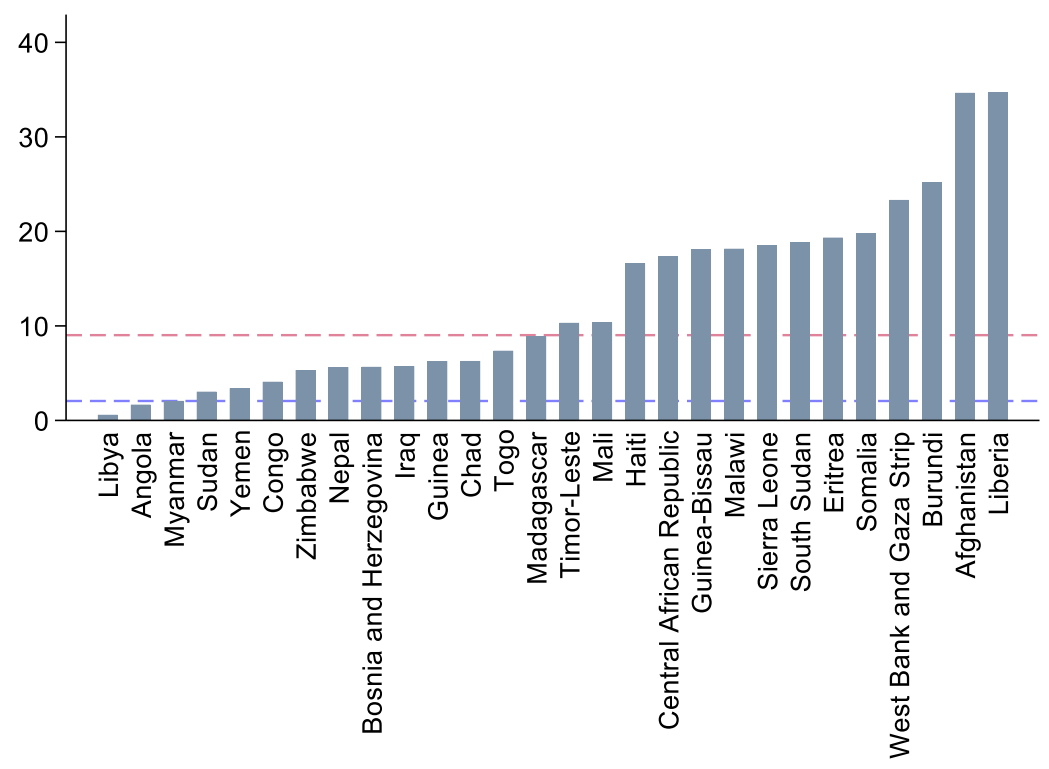

Notes: the bars report the median ODA to GDP over the period 1990-2017. The dashed red (blue) line corresponds to the median ODA to GDP in fragile (non-fragile) states. We exclude countries with a population below 1000000 inhabitants. 
Figure 3: Aid, foreign direct investment and remittances to fragile states

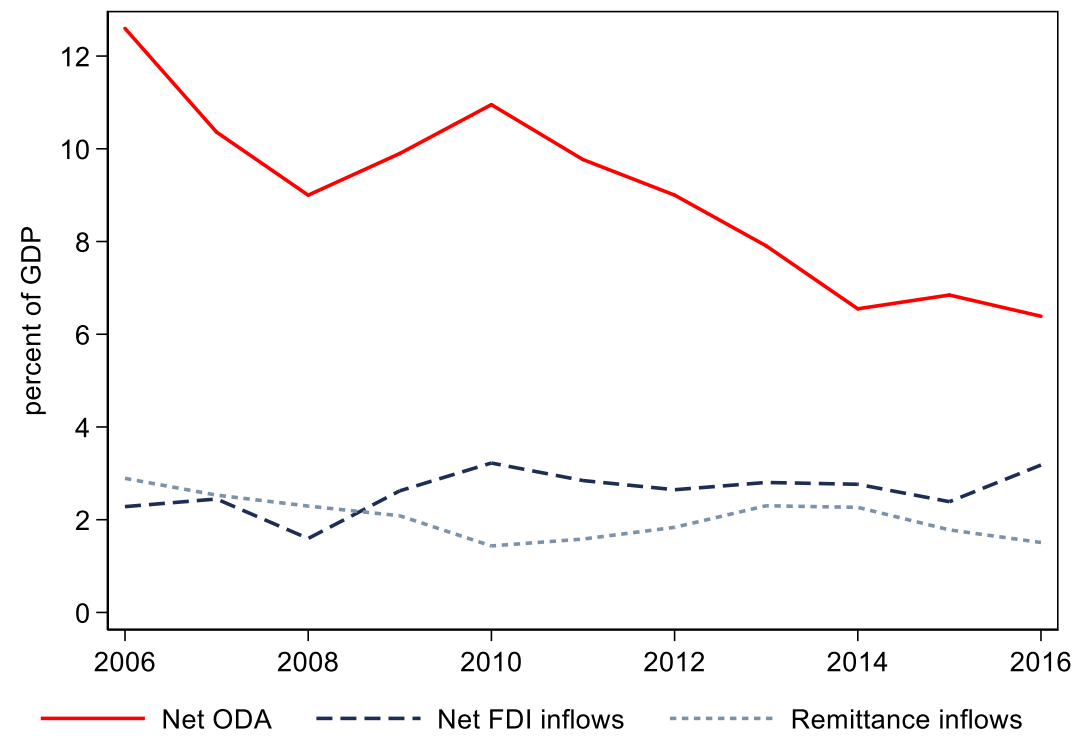

Notes: the chart reports the median ratios of net ODA, net FDI inflows and remittance inflows, as percent of GDP, for a sample of 31 fragile states, selected to have a minimum of 6 observations (jointly for the three ratios) over the sample period 2006-2016.

Figure 4. Aid unpredictability

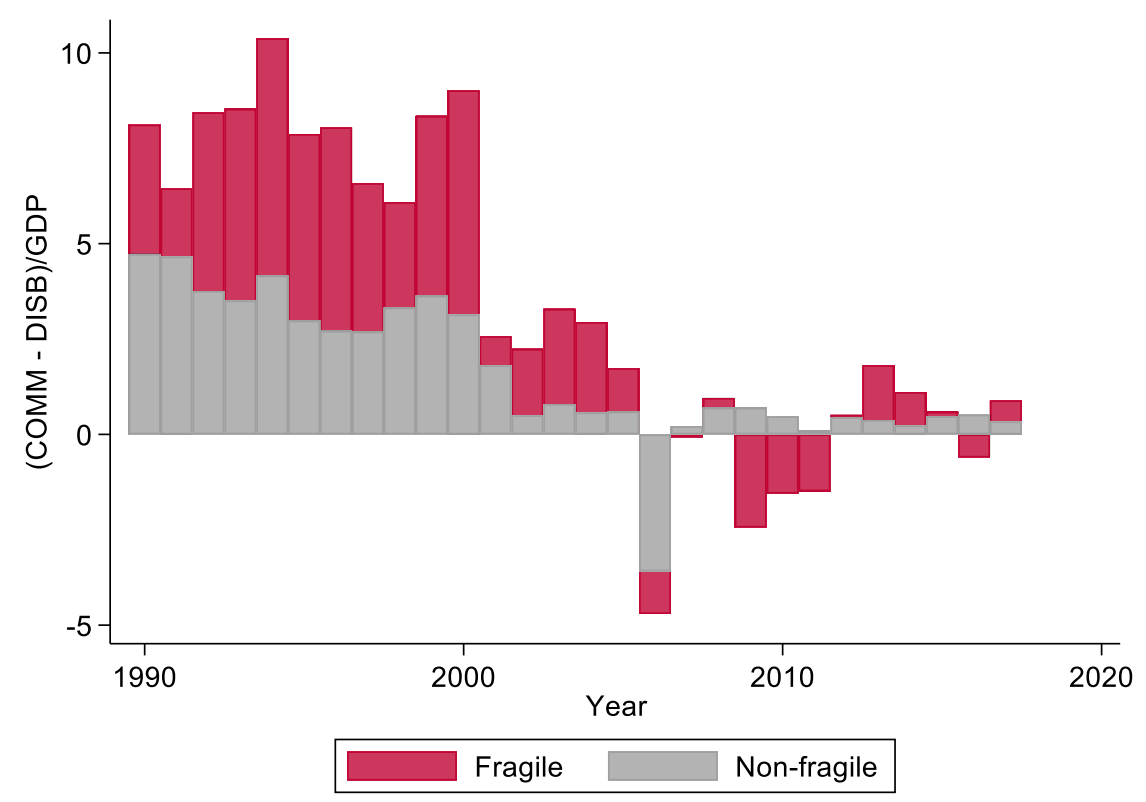

Notes: the chart reports the ratio of the difference between commitments and disbursement (a proxy for unpredictability) to nominal GDP for both fragile and non-fragile countries. 
Figure 5. Different measures of donor fragmentation in fragile states

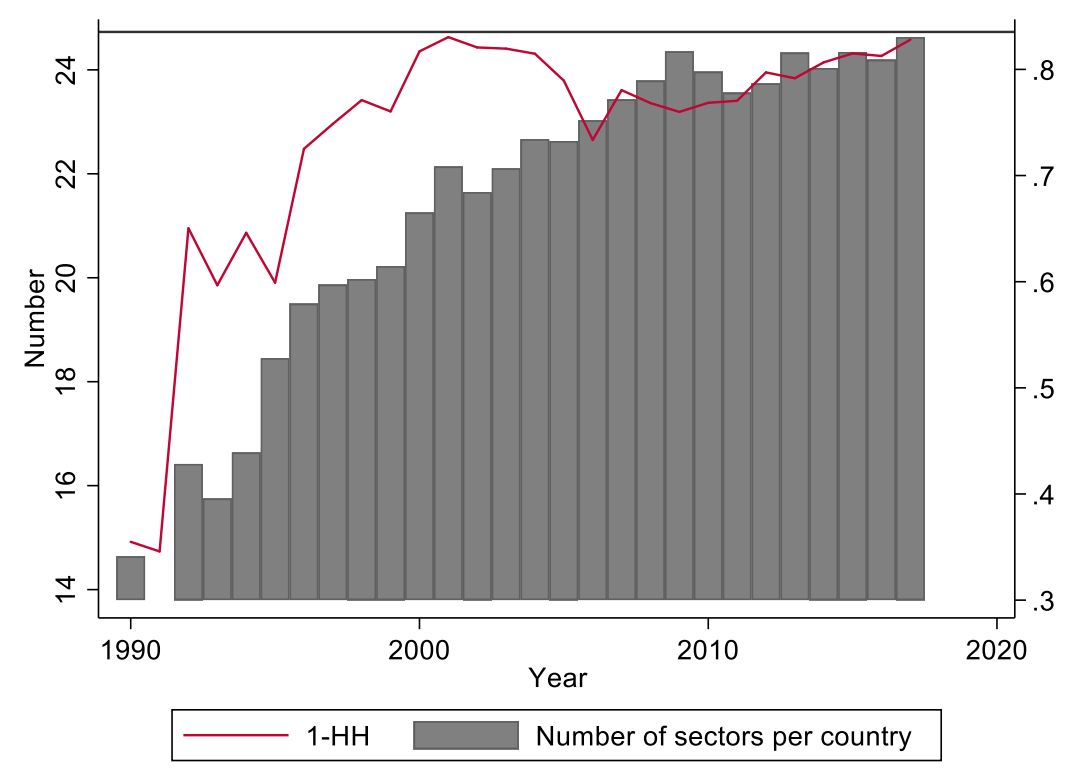

Notes: the grey bars report the average number of donors in fragile states. The red line corresponds to fragmentation across donors computed as $1-$ the Herfindahl Index. The dashed line is the median average of donors in non-fragile countries.

Figure 6. Sectoral allocation in fragile countries

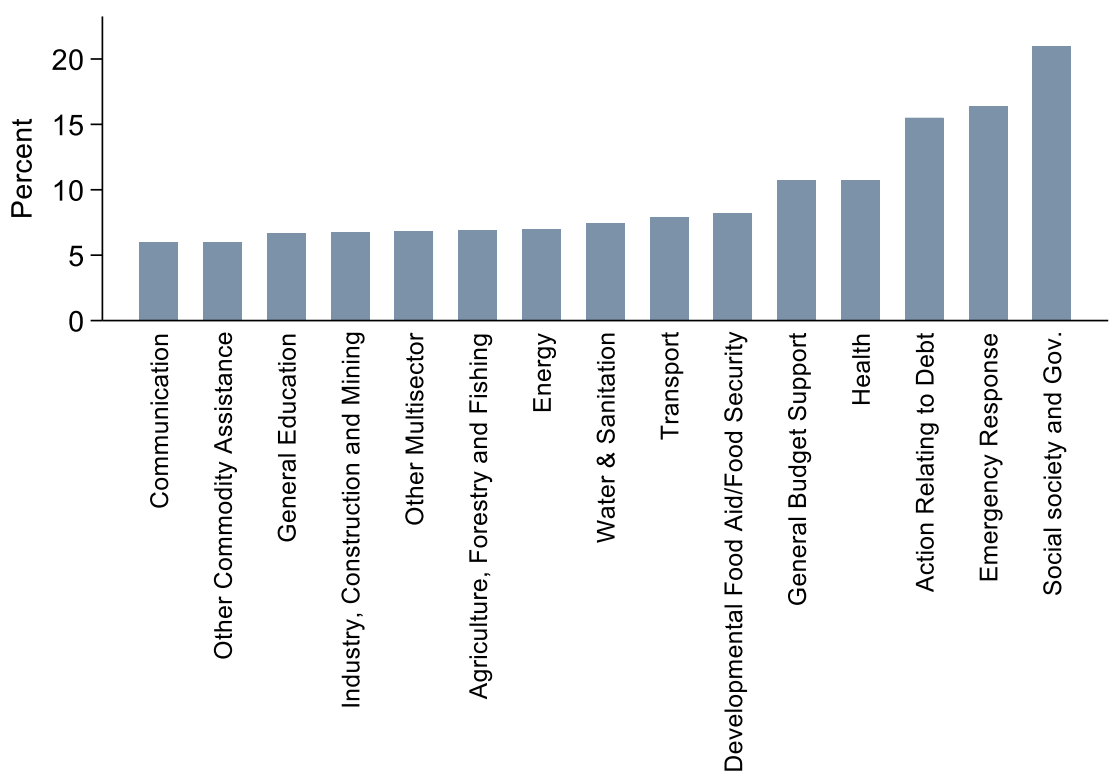

Notes: the sectoral allocation is based on the DAC CRS classification. We consider the 3-digit classification and we group several subsectors to ease visualization. We exclude sectors that are classified as "Unallocated". 
Figure 7. Evolution of budget support vs project aid

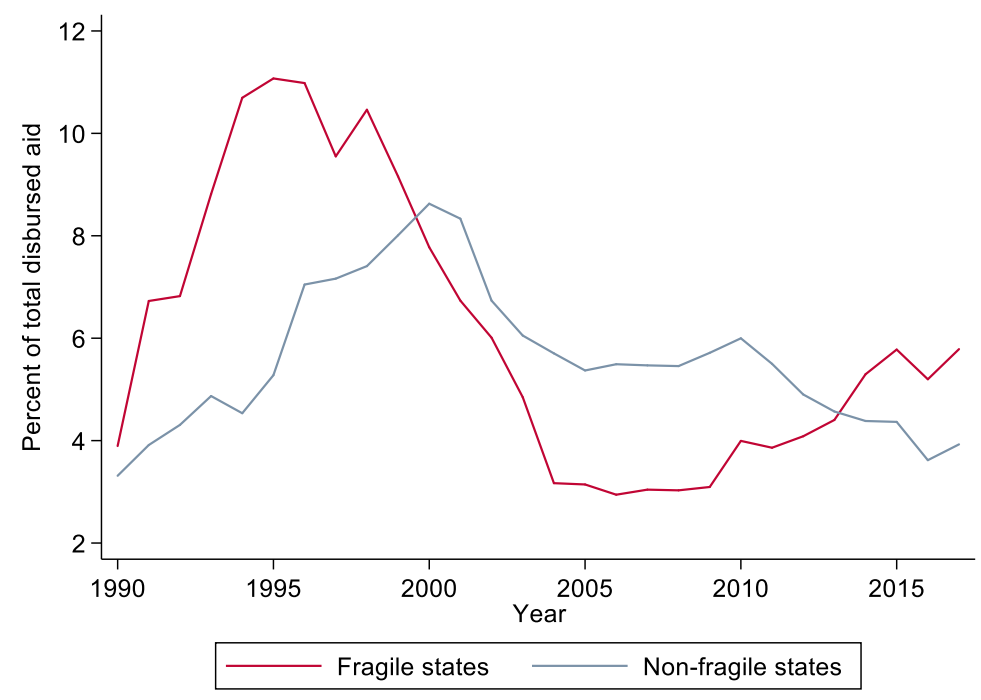

Notes: the chart reports the 5-year moving average of budget support disbursements as a share of total disbursed aid in fragile and non-fragile states. Budget support aid corresponds to the CRS code 510.

Figure 8. Share of succesfull projects

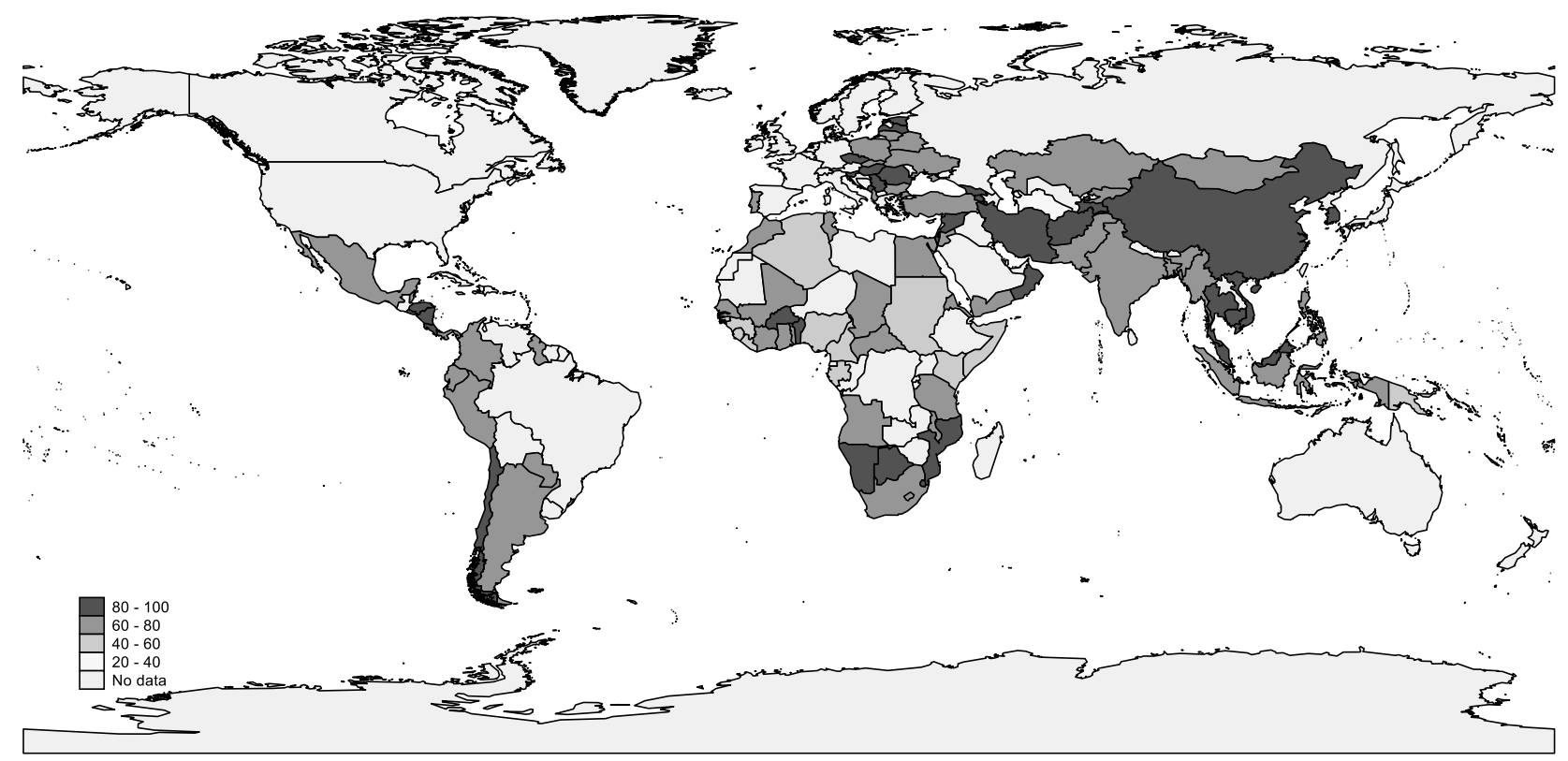

Note: the map reports the number of successful projects as a share of total projects by country. We consider only country that reports at least 3 projects. Data are from Honig (2018) and available here: Project Performance Database February 2019, https://doi.org/10.7910/DVN/444GNW, Harvard Dataverse, V1. 
Figure 9. Share of successful projects

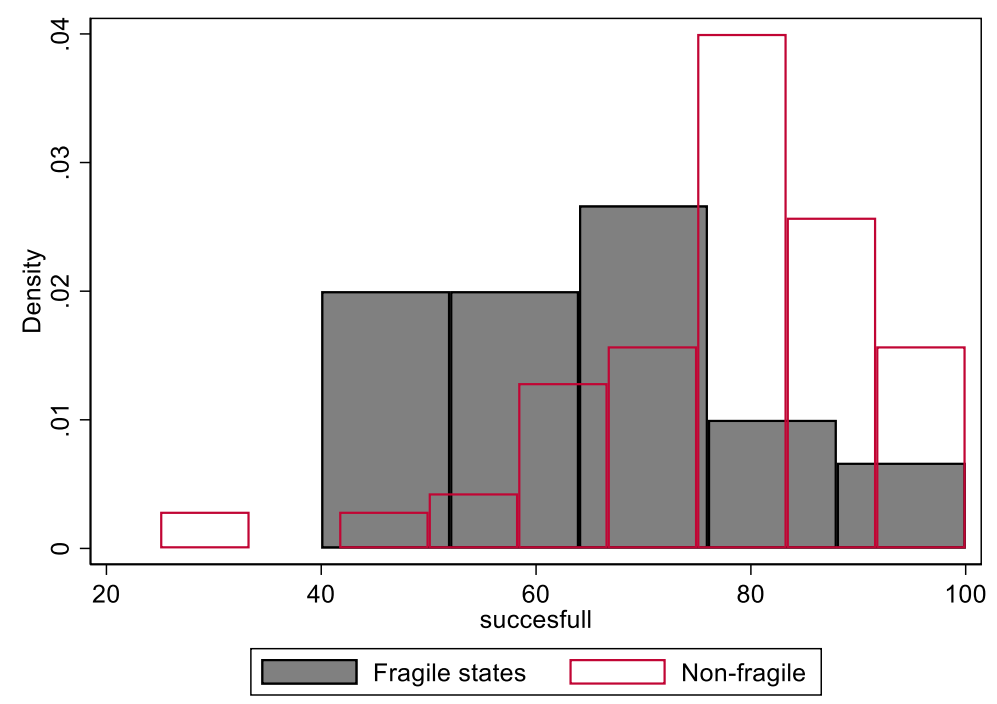

Note: the chart reports the share of successful projects to total projects calculated at the country level. We consider only countries where at least 3 projects were implemented.

Figure 10. Control of corruption, fragile and non-fragile states

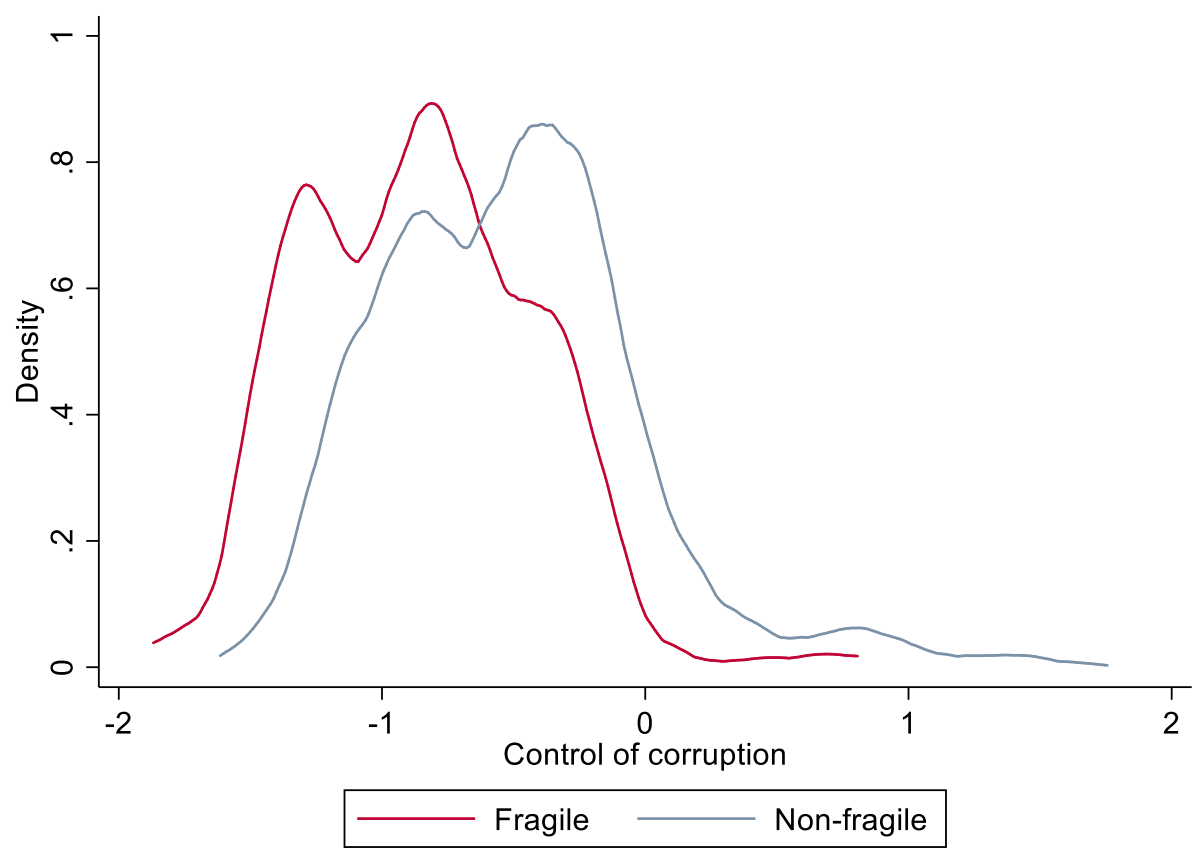

Note: the figure reports the distribution of the variable control of corruption from the World Bank "Worldwide Governance Indicators" for both fragile and non-fragile countries. 
Tables

Table 1. Project outcomes in fragile states

\begin{tabular}{llll|lll}
\hline \multicolumn{4}{c|}{ Non-fragile } & \multicolumn{3}{l}{ Fragile } \\
\hline Variable & Obs. & Mean & St. dev & Obs. & Mean & St. dev \\
Project duration & 8127 & 6.5 & 2.7 & 1392 & 6.1 & 2.9 \\
Lag to evaluation & 8255 & 2.3 & 2 & 1418 & 2.5 & 2.3 \\
Office presence & 7974 & 0.8 & 0.4 & 1263 & 0.7 & 0.5 \\
\hline
\end{tabular}

Notes: the table reports the summary statistics of the project level characteristics.

Table 2. Project outcomes in fragile states

\begin{tabular}{|c|c|c|c|c|c|c|c|c|}
\hline \multirow[b]{2}{*}{ VARIABLES } & \multicolumn{2}{|l|}{ (1) } & \multirow{2}{*}{\multicolumn{2}{|c|}{ (3) }} & \multirow{2}{*}{\multicolumn{2}{|c|}{$(5)$}} & \multicolumn{2}{|l|}{ (7) } \\
\hline & Project ratin & $\lg (1-6)$ & & & & & Project ratil & $\operatorname{ng}(0 / 1)$ \\
\hline Fragile states dummy & $\begin{array}{l}-0.1768 * * * \\
(0.058)\end{array}$ & $\begin{array}{l}-0.1975 * * * \\
(0.064)\end{array}$ & $\begin{array}{l}-0.0735 * * * \\
(0.022)\end{array}$ & $\begin{array}{l}-0.0808 * * * \\
(0.024)\end{array}$ & $\begin{array}{l}-0.1748 * \\
(0.097)\end{array}$ & $\begin{array}{l}-0.1985 * \\
(0.115)\end{array}$ & $\begin{array}{l}-0.0742 * * \\
(0.037)\end{array}$ & $\begin{array}{l}-0.0786^{*} \\
(0.045)\end{array}$ \\
\hline Growth & $\begin{array}{l}0.0789 * * * \\
(0.007)\end{array}$ & $\begin{array}{l}0.0750 * * * \\
(0.008)\end{array}$ & $\begin{array}{l}0.0226 * * * \\
(0.003)\end{array}$ & $\begin{array}{l}0.0216^{* * * *} \\
(0.003)\end{array}$ & $\begin{array}{l}0.0726^{* * * *} \\
(0.011)\end{array}$ & $\begin{array}{l}0.0777 * * * \\
(0.013)\end{array}$ & $\begin{array}{l}0.0211 * * * \\
(0.004)\end{array}$ & $\begin{array}{l}0.0234 * * * \\
(0.005)\end{array}$ \\
\hline Volatility of growth & $\begin{array}{l}-0.0273^{* * *} \\
(0.008)\end{array}$ & $\begin{array}{l}-0.0299 * * * \\
(0.008)\end{array}$ & $\begin{array}{l}-0.0069^{* *} \\
(0.003)\end{array}$ & $\begin{array}{l}-0.0076^{* *} \\
(0.003)\end{array}$ & $\begin{array}{l}-0.0218^{*} \\
(0.011)\end{array}$ & $\begin{array}{l}-0.0298 * * \\
(0.014)\end{array}$ & $\begin{array}{l}-0.0044 \\
(0.004)\end{array}$ & $\begin{array}{l}-0.0071 \\
(0.006)\end{array}$ \\
\hline Project duration & $\begin{array}{l}0.0093 \\
(0.036)\end{array}$ & $\begin{array}{l}-0.0186 \\
(0.040)\end{array}$ & $\begin{array}{l}0.0026 \\
(0.013)\end{array}$ & $\begin{array}{l}-0.0072 \\
(0.015)\end{array}$ & $\begin{array}{l}0.0661 \\
(0.063)\end{array}$ & $\begin{array}{l}0.0154 \\
(0.074)\end{array}$ & $\begin{array}{l}0.0050 \\
(0.023)\end{array}$ & $\begin{array}{l}-0.0130 \\
(0.028)\end{array}$ \\
\hline Lag to evaluation & $\begin{array}{l}-0.0047 \\
(0.036)\end{array}$ & $\begin{array}{l}-0.0333 \\
(0.040)\end{array}$ & $\begin{array}{l}-0.0031 \\
(0.013)\end{array}$ & $\begin{array}{l}-0.0134 \\
(0.015)\end{array}$ & $\begin{array}{l}0.0189 \\
(0.065)\end{array}$ & $\begin{array}{l}-0.0378 \\
(0.078)\end{array}$ & $\begin{array}{l}-0.0154 \\
(0.024)\end{array}$ & $\begin{array}{l}-0.0360 \\
(0.029)\end{array}$ \\
\hline Office presence & $\begin{array}{l}0.0119 \\
(0.058)\end{array}$ & $\begin{array}{l}0.0664 \\
(0.068)\end{array}$ & $\begin{array}{l}0.0036 \\
(0.021)\end{array}$ & $\begin{array}{l}0.0105 \\
(0.026)\end{array}$ & $\begin{array}{l}-0.0866 \\
(0.093)\end{array}$ & $\begin{array}{l}-0.0698 \\
(0.125)\end{array}$ & $\begin{array}{l}-0.0159 \\
(0.033)\end{array}$ & $\begin{array}{l}-0.0221 \\
(0.045)\end{array}$ \\
\hline WB project cost & & & & & $\begin{array}{l}0.0394^{*} \\
(0.021)\end{array}$ & $\begin{array}{l}0.0442 \\
(0.028)\end{array}$ & $\begin{array}{l}0.0080 \\
(0.008)\end{array}$ & $\begin{array}{l}0.0072 \\
(0.010)\end{array}$ \\
\hline Observations & 7,995 & 7,717 & 7,995 & 7,717 & 2,747 & 2,565 & 2,747 & 2,565 \\
\hline R-squared & 0.158 & 0.282 & 0.104 & 0.229 & 0.145 & 0.351 & 0.120 & 0.331 \\
\hline Region \& income FE & Yes & Yes & Yes & Yes & Yes & Yes & Yes & Yes \\
\hline Donor FE & Yes & Yes & Yes & Yes & Yes & Yes & Yes & Yes \\
\hline Time \& sector FE & Yes & No & Yes & No & Yes & No & Yes & No \\
\hline Approval year X sector FE & No & Yes & No & Yes & No & Yes & No & Yes \\
\hline Evaluation year $\mathrm{X}$ sector $\mathrm{FE}$ & No & Yes & No & Yes & No & Yes & No & Yes \\
\hline Evaluation year FE & Yes & No & Yes & No & Yes & No & Yes & No \\
\hline Lending type FE & No & No & No & No & Yes & Yes & Yes & Yes \\
\hline Project vars & Yes & Yes & Yes & Yes & Yes & Yes & Yes & Yes \\
\hline Sample & All & All & All & All & WB & WB & WB & WB \\
\hline R2adj & 0.1456 & 0.1587 & 0.0914 & 0.0964 & 0.1121 & 0.1302 & 0.0865 & 0.1022 \\
\hline
\end{tabular}

Notes: The table reports the results from Equation (1). Standard errors are clustered at the country-approval year level. Column (1)-(4) reports the results for the full sample, while Column (5)-(6) report the results for World Bank projects only. 
Table 3. Project outcomes and conflicts

\begin{tabular}{lllll}
\hline & \multicolumn{1}{c}{$(1)$} & \multicolumn{1}{c}{$(2)$} & \multicolumn{1}{c}{$(3)$} & \multicolumn{1}{c}{$(4)$} \\
Dependent variable: & \multicolumn{1}{c}{ Project rating $(1-6)$} & Project rating $(0 / 1)$ \\
\hline & & & & \\
Conflict & $-0.2761^{* * *}$ & $-0.2402^{* *}$ & $-0.0725^{* *}$ & $-0.0685^{* *}$ \\
& $(0.091)$ & $(0.095)$ & $(0.032)$ & $(0.034)$ \\
Growth & $0.0538^{* * *}$ & $0.0528^{* * *}$ & $0.0122^{* * *}$ & $0.0117^{* * *}$ \\
& $(0.010)$ & $(0.010)$ & $(0.004)$ & $(0.004)$ \\
Volatility of growth & $-0.0216^{* *}$ & $-0.0253^{* *}$ & $-0.0077^{* *}$ & $-0.0088^{* *}$ \\
& $(0.010)$ & $(0.010)$ & $(0.004)$ & $(0.004)$ \\
& & & & \\
\hline Observations & 7,990 & 7,850 & 7,990 & 7,850 \\
R-squared & 0.141 & 0.231 & 0.105 & 0.191 \\
Country FE & Yes & Yes & Yes & Yes \\
Sector X Year & No & Yes & No & Yes \\
Evaluation year FE & Yes & Yes & Yes & Yes \\
Year FE & Yes & No & Yes & No \\
Project vars & Yes & Yes & Yes & Yes \\
Sample & All & All & All & All \\
R2adj & 0.1188 & 0.1427 & 0.0820 & 0.0979 \\
\hline
\end{tabular}

Note: The table reports the results from Equation (2). Standard errors are clustered at the country-approval year level. 
Table 4. Project outcomes and corruption

\begin{tabular}{lllll}
\hline & $(1)$ & $(2)$ & $(3)$ & $(4)$ \\
Dependent variable: & Rating $(1-6)$ & & Rating $(0 / 1)$ & \\
\hline & & & & \\
Fragile states dummy & -0.0746 & -0.1164 & -0.0227 & -0.0268 \\
& $(0.098)$ & $(0.135)$ & $(0.042)$ & $(0.055)$ \\
GDP Growth & $0.0807^{* * *}$ & $0.0747^{* * *}$ & $0.0221^{* * *}$ & $0.0193^{* * *}$ \\
& $(0.013)$ & $(0.014)$ & $(0.005)$ & $(0.006)$ \\
GDP Growth volatility & -0.0141 & -0.0124 & -0.0007 & 0.0006 \\
& $(0.015)$ & $(0.019)$ & $(0.006)$ & $(0.007)$ \\
Control of corruption & $0.2261^{* * *}$ & $0.1495^{*}$ & $0.0831^{* * *}$ & $0.0571^{*}$ \\
& $(0.070)$ & $(0.079)$ & $(0.027)$ & $(0.030)$ \\
& & & & \\
\hline Observations & 1,988 & 1,843 & 1,988 & 1,843 \\
Region \& income FE & Yes & Yes & Yes & Yes \\
Donor FE & Yes & Yes & Yes & Yes \\
Time \& sector FE & Yes & No & Yes & No \\
Approval year X sector FE & No & Yes & No & Yes \\
Evaluation year X sector FE & No & Yes & No & Yes \\
Project controls & Yes & Yes & Yes & Yes \\
$\mathrm{R}^{2}-$ adjusted & 0.1695 & 0.2043 & 0.0727 & 0.0925 \\
\hline
\end{tabular}

Notes: The table reports the results from Equation (2) augmented with a term that capture the level of control of corruption. Standard errors are clustered at the country-approval year level 
Table 5. Project outcomes and conflicts at the regional level

\begin{tabular}{lllll}
\hline & $(1)$ & $(2)$ & $(3)$ & $(4)$ \\
Dependent variable: & Rating $(1-6)$ & & Rating $(0 / 1)$ & \\
\hline & & & & \\
Conflict dummy & -0.0376 & -0.0684 & $-0.0534^{* *}$ & $-0.0641^{*}$ \\
Project cost & $(0.056)$ & $(0.086)$ & $(0.025)$ & $(0.035)$ \\
& $0.0782^{* * *}$ & $0.0858^{* * *}$ & $0.0226^{* * *}$ & $0.0243^{* * *}$ \\
Project duration & $(0.020)$ & $(0.021)$ & $(0.008)$ & $(0.008)$ \\
& $-0.0437^{* *}$ & $-0.0408^{* *}$ & -0.0081 & -0.0075 \\
GDP Growth & $(0.019)$ & $(0.018)$ & $(0.007)$ & $(0.007)$ \\
& $0.0657^{* * *}$ & $0.0725^{* * *}$ & $0.0187^{* *}$ & $0.0220^{* * *}$ \\
GDP Growth volatility & $(0.022)$ & $(0.022)$ & $(0.008)$ & $(0.008)$ \\
& -0.0322 & -0.0387 & -0.0059 & -0.0084 \\
& $(0.026)$ & $(0.026)$ & $(0.010)$ & $(0.011)$ \\
\hline Observations & & & & \\
Region FE & 3,145 & 3,054 & 3,145 & 3,054 \\
Country FE & No & Yes & No & Yes \\
Year FE & Yes & No & Yes & No \\
Evaluation Year FE & Yes & Yes & Yes & Yes \\
Sector FE & Yes & Yes & Yes & Yes \\
$\mathrm{R}^{2}$ - adjusted & Yes & Yes & Yes & Yes \\
\hline & 0.2812 & 0.2175 & 0.2052 & 0.1337 \\
\hline
\end{tabular}

Notes: The table reports the results from Equation (3). Standard errors are clustered at the ADM1 level. 